Brown, R., Robinson, E. \& Johnson, A. W. (1949). Proc. Roy. Soc. B, 136, 577.

Bryson, J. L. \& Mitchell, T. J. (1951). Nature, Lond., 167, 864.

Byrne, W. L. \& Lardy, H. A. (1954). Biochim. biophys. Acta, $14,495$.

Dickens, F. (1938). Biochem. J. 32, 1626.

Dickens, F. (1955). Proc. 3rd Int. Congr. Biochem., Brussels, Conférences et Rapports, p. 170.

Dickens, F. \& Glock, G. E. (1951). Biochem. J. 50, 81.

Dickens, F. \& Williamson, D. H. (1955). Nature, Lond., 176, 400.

Dische, Z. (1953). J. biol. Chem. 204, 983.

Dische, Z. \& Borenfreund, E. (1951). J. biol. Chem. 192 , 583.

Glatthaar, C. \& Reichstein, T. (1935). Helv. chim. acta, 18, 80.

Glock, G. E. (1952). Biochem. J. 52, 575.

Glock, G. E. \& McLean, P. (1953). Biochem. J. 55, 400.

Glock, G. E. \& McLean, P. (1954). Biochem. J. 56, 171.

Gunsalus, I. C., Horecker, B. L. \& Wood, W. A. (1955). Bact. Rev. 19, 79.

Hele, M. P. (1953). Biochem. J. 55, 857.

Hochster, R. M. (1955). Canad. J. Microbiol. 1, 346.

Horecker, B. L., Hurwitz, J. \& Smyrniotis, P. Z. (1956). J. Amer. chem. Soc. 78, 692.

Horecker, B. L., Smyrniotis, P. Z. \& Klenow, H. (1953). J. biol. Chem. 205, 661.

Horecker, B. L., Smyrniotis, P. Z. \& Seegmiller, J. E. (1951). $J$. biol. Chem. 193, 383.

Hough, L. \& Jones, J. K. N. (1952). J. chem. Soc. p. 4047.
Khym, J. X. \& Cohn, W. E. (1953). J. Amer. chem. Soc. 75, 1153.

Khym, J. X. \& Zill, L. P. (1952). J. Amer. chem. Soc. 74, 2090.

Klevstrand, R. \& Nordal, A. (1950). Acta chem. scand. 4, 1320.

Lampen, J. O. (1953). J. biol. Chem. 204, 999.

Levene, P. A. \& Tipson, R. S. (1936). J. biol. Chem. 115, 731.

McGeown, M. \& Malpress, F. H. (1954). Nature, Lond., 173, 212.

Mejbaum, W. (1939). Hoppe-Seyl. Z. 258, 117.

Mitsuhashi, S. \& Lampen, J. O. (1953). J. biol. Chem. 204, 1011.

Moffatt, J. G. \& Khorana, H. G. (1956). J. Amer. chem. Soc. $78,883$.

Nelson, N. (1944). J. biol. Chem. 153, 375.

Racker, E. (1954). Advanc. Enzymol. 15, 141.

Reichstein, T. (1934). Helv. chim. acta, 17, 996.

Sable, H. Z. (1952). Biochim. biophys. Acta, 8, 687.

Schäffner, A. (1941). In Die Methoden der Fermentforschung, p. 1678. Ed. by Bamann, E. \& Myrbäck, K. Leipzig: Thieme.

Sibley, J. A. \& Lehninger, A. L. (1949). J. biol. Chem. 177, 859.

Sols, A. (1956). Biochim. biophys. Acta, 19, 144.

Srere, P. A., Cooper, J. R., Klybas, V. \& Racker, E. (1955). Arch. Biochem. Biophys. 59, 535.

Stumpf, P. K. \& Horecker, B. L. (1956). J. biol. Chem. 218, 753.

Woolf, L. I. (1953). Nature, Lond., 171, 841.

\title{
The Metabolism of Tryptophan
}

\section{THE METABOLISM OF TRYPTOPHAN IN PATIENTS SUFFERING FROM CANCER OF THE BLADDER*}

\author{
BY E. BOYLAND AND D. C. WILLIAMS \\ Chester Beatty Research Institute, Institute of Cancer Research, Royal Cancer Hospital, \\ Fulham Road, London, S.W. 3
}

\section{(Received 26 April 1956)}

Observations on cancer of the bladder, among dye workers and other groups susceptible to the action of external carcinogens, suggest that a certain proportion of tumours previously considered to be spontaneous may in fact be produced by chemical carcinogens derived either from the environment or from the metabolic processes of the organism itself (Boyland, Wallace \& Williams, 1955 $a, b$ ).

The investigations of Hueper \& Wolfe (1937), Hueper, Wiley \& Wolfe (1938), Bonser (1943), Bonser, Clayson, Jull \& Pyrah (1952) and others have shown that a number of $o$-aminophenols can

* Part 1: Boyland, Sims \& Williams (1956). induce cancer of the bladder in mice and dogs. The o-aminophenols 3-hydroxykynurenine and 3-hydroxyanthranilic acid are metabolites of tryptophan and are present in human urine both in the free state and conjugated as sulphuric and glucosiduronic esters. Boyland \& Watson (1956) have shown that insertion of pellets containing 3-hydroxyanthranilic acid into the urinary bladder of mice induces cancer in a statistically significant proportion of animals. The present work deals with a system which has been evolved for the extraction of six metabolites of tryptophan from urine and their estimation. Preliminary reports of this work have already been published (Boyland \& Williams, 1955 $a, b$ ). 


\section{EXPERIMENTAL}

Materials. Anthranilic acid, DL-kynurenine and 3hydroxyanthranilic acid were purchased and recrystallized. 3-Hydroxy-DL-kynurenine, the gift of Professor A. Butenandt, was prepared by the method of Butenandt \& Hellmann (1950). 3-Hydroxyanthranilic acid sulphuric ester was prepared by the method of Boyland \& Sims (1954). 3-Hydroxy-DL-kynurenine sulphuric ester was prepared by the action of potassium persulphate on DL-kynurenine (Boyland, Sims \& Williams, 1956). Glucosaccharo-1:4lactone (Kemball, Bishop and Co. Ltd., Crown Chemical Works, London, E. 3) was supplied in solution containing glucosaccharo-3:6-lactone, glucosaccharic acid and glucosaccharo-1:4-lactone, the last forming about $40 \%$ of the total solid. An amount of the solution equivalent to $4 \mathrm{~g}$. of glucosaccharo-1:4-lactone was administered daily.

\section{Preliminary extraction of urine}

Activated charcoal (British Drug Houses Ltd.) was deactivated by the method of Synge \& Tiselius (1949). This preparation has been used for the extraction of tryptophan metabolites from rat urine by Dalgliesh (1952). Preliminary experiments were carried out with columns $(1 \mathrm{~cm}$. in diameter and $1 \mathrm{~cm}$. long) of charcoal deactivated with various amounts of stearic acid. A solution of the substances to be estimated ( $25 \mu \mathrm{g}$. of each dissolved in $25 \mathrm{ml}$. of water) was passed through the charcoal column, the column was then washed with $25 \mathrm{ml}$. of water and eluted with aqueous phenol $(5 \%, \mathrm{w} / \mathrm{v})$ and the eluate collected in $10 \mathrm{ml}$. portions. Each fraction was evaporated to dryness and dissolved in water $(5 \mathrm{ml}$.$) , and the eluted substances were estimated by$ their fluorescence, with an Electronic Photofluorometer 12 A (Coleman Electric Co., New York). The results obtained with charcoal of various degrees of deactivation are shown in Fig. 1. They indicate that a column deactivated with $7.5 \%(w / v)$ of stearic acid gives an optimum recovery, and the charcoal of this activity has been used throughout the present work.

Urine (25 ml.) was passed through the charcoal column, followed by water $(25 \mathrm{ml}$.), and then the adsorbed substances were eluted by phenol solution $(50 \mathrm{ml} ., 5 \% \mathrm{w} / \mathrm{v})$. The eluate was evaporated to dryness, $10 \mathrm{ml}$. of methanol added and the liquid again evaporated to dryness. The residue was dissolved in a minimum of water and transferred to the partition column.

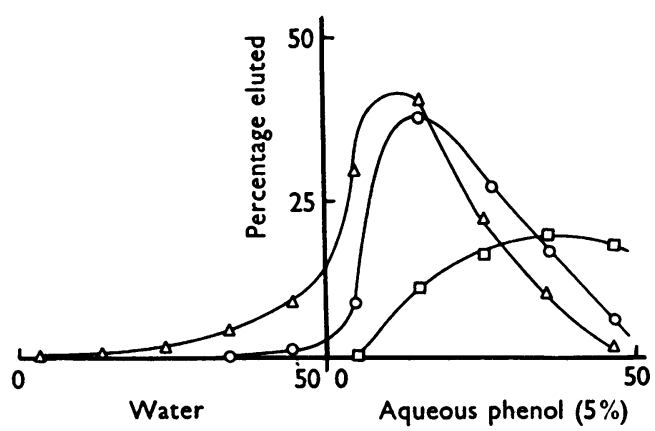

Fig. 1. Elution of a mixture of tryptophan metabolites from charcoal columns deactivated with: $\Delta, 10 \%$; $0,7 \cdot 5 \% ; \square, 5 \%(w / w)$ stearic acid.

\section{Partition chromatography}

Solvents. Light petroleum (b.p. 60-80 ) was dried over anhydrous $\mathrm{Na}_{3} \mathrm{SO}_{4}$ and redistilled. Amyl alcohol containing dodecylamine was prepared from amyl alcohol (British Standard 696) redistilled after drying over anhydrous $\mathrm{Na}_{2} \mathrm{SO}_{4}$. Dodecylamine $(0.5 \% \mathrm{w} / \mathrm{v}$, Light and Co.) was dissolved in the amyl alcohol and the resulting slightly opaque solution was centrifuged (2000 rev./min. for $30 \mathrm{~min}$.) and decanted from the deposited impurity.

Apparatus. The apparatus used for gradient elution from a partition column, shown in Fig. 2 (not drawn to scale), is a modification of that used by Morris \& Williams (1954).

The reservoir $A$ was filled with light petroleum and the reservoir $B$ with amyl alcohol containing dodecylamine, and both were placed in position on the U-tube $E F$ with taps $T_{1}, T_{2}$ and $T_{3}$ closed. Taps $T_{1}$ and $T_{2}$ were opened and the liquids adjusted so that the interface was at the junction $p$. The apparatus was then assembled and $T_{3}$ opened. The solvent mixture after passing through the offset mixing bulbs $q$, bubbled in a fine stream through the vessel $C$ which
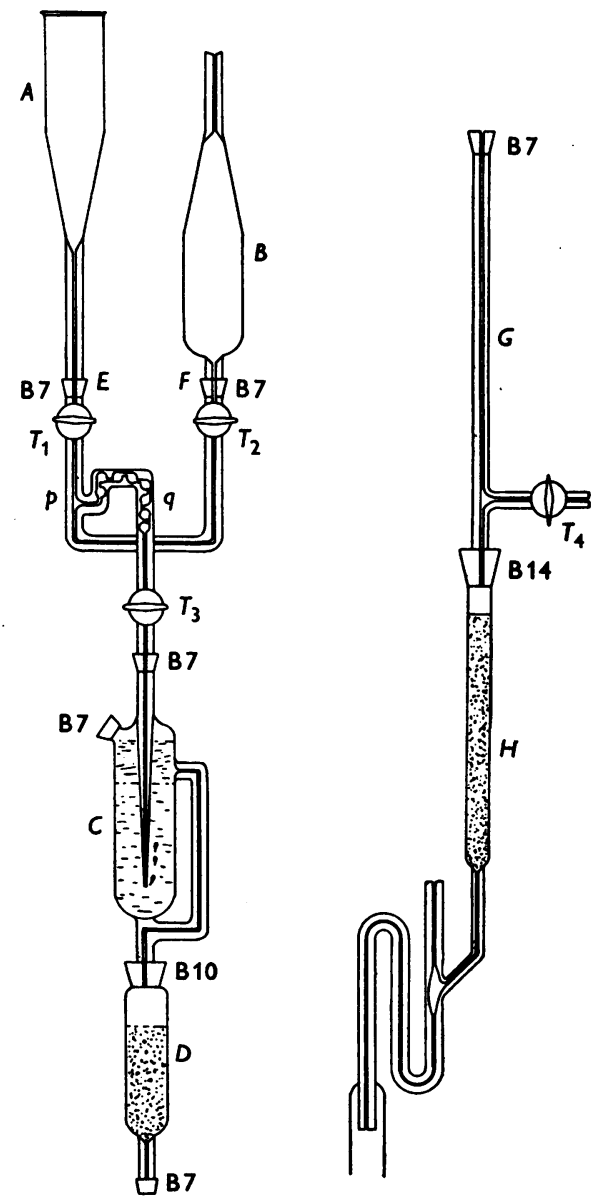

Fig. 2. Apparatus for gradient partition column chromatography. 
contained water, thus equilibrating the moving with the stationary phase. The equilibration was completed by passing the solvent mixture through the column $D(0.8 \mathrm{~cm}$. in diameter and $6 \mathrm{~cm}$. long) consisting of Hyflo Super-Cel (Johns Manville Co. Ltd., London, S.W. 1) containing water (1 ml./g.). The solvent mixture then passed via the tube $G$ to the partition column $H$. The tap $T_{4}$ serves to remove air from the system at the start of the experiment. The column $H, 0.5 \mathrm{~cm}$. in diameter and $8 \mathrm{~cm}$. long, was packed with Hyflo Super-Cel containing $50 \%(w / v)$ of water as a stationary phase by means of a Martin packer (Randall \& Martin, 1949). The extract from the charcoal column was dissolved in a minimum of water and added to a layer $(0.5 \mathrm{~cm}$.) of dry Super-Cel which had been packed on

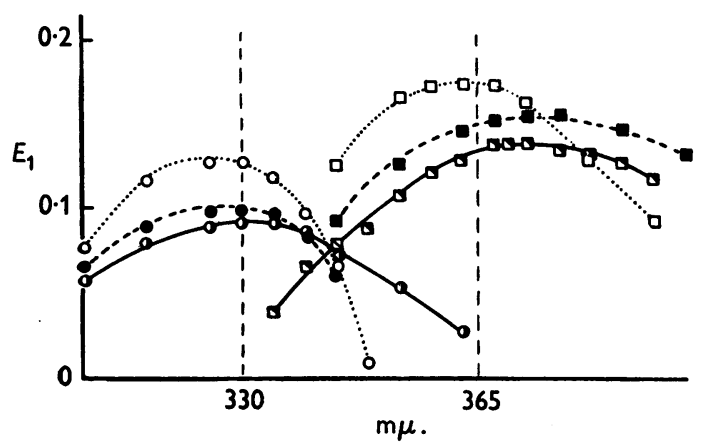

Fig. 3. Optimum absorption of some metabolic products of tryptophan in the ultraviolet. Kynurenine $(\square \cdots \square)$; 3-hydroxykynurenine $(\Delta-\Delta)$; 3-hydroxykynurenine sulphuric ester (.$--\square)$; anthranilic acid $(0 \cdots O)$; 3-hydroxyanthranilic acid $(0-0)$; 3-hydroxyanthranilic acid sulphuric ester (0- - $)$.

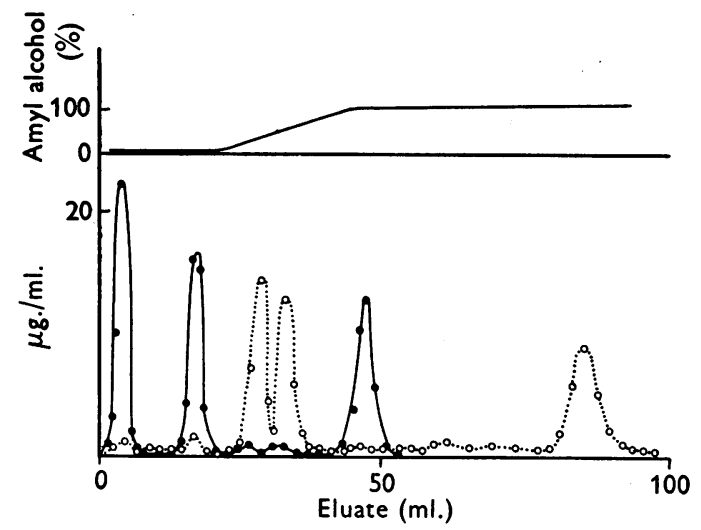

Fig. 4. Chromatographic separation of some metabolites of tryptophan from urine. Substances estimated at $330 \mathrm{~m} \mu$. (O-); substances estimated at $365 \mathrm{~m} \mu$. (O... O); percentage of amyl alcohol in the eluate $(-)$. The peaks correspond to anthranilic acid (1-8 ml.), 3-hydroxyanthranilic acid (12-18 ml.), kynurenine (23-30 ml.), 3-hydroxykynurenine (31-37 ml.), 3-hydroxyanthranilic acid sulphuric ester $(42-50 \mathrm{ml}$.) and 3-hydroxykynurenine sulphuric ester (78-90 $\mathrm{ml}$.).

the top of the column $H$. The moving phase was then allowed to pass through the column under its own head of pressure and the eluate collected in $1 \mathrm{ml}$. portions by means of a siphon and a weight-operated fraction collector.

The modified apparatus has the following advantages: (a) The standard joints $E$ and $F$ allow the two halves of the apparatus to be filled separately before the apparatus is assembled. (b) The shape of the gradient can be varied by the addition of suitable adaptors at $E$ and $F$ and the gradient can also be changed by substituting reservoirs of appropriate shapes for $A$ and $B$. (c) The system shown is suitable for a change from a light to a more dense liquid, but the opposite gradient can be obtained by interchanging $A$ and $B$. $(d)$ The solvents from $A$ and $B$ are mixed together before being equilibrated with the stationary phase. This avoids precipitation of excess of stationary phase, which otherwise occurs if this phase is considerably more miscible in one component than in the other.

Estimation. The eluate from the partition column was collected in 100 fractions and each fraction adjusted to $1 \mathrm{ml}$. if any evaporation had taken place. Freshly redistilled ethanol ( $2 \mathrm{ml}$.) was added to each tube, the mixture shaken and the amounts of the various substances were estimated on the Unicam SP. 500 spectrophotometer. Fig. 3 shows the positions of peaks in the ultraviolet spectra of the substances. Kynurenine and its derivatives show peak values between 360 and $375 \mathrm{~m} \mu$., and anthranilic acid and its derivatives between 320 and $330 \mathrm{~m} \mu$. These compounds were therefore estimated at 365 and $330 \mathrm{~m} \mu$. respectively and compared with standard solutions of the pure substances. The separation obtained by using this system is shown in Fig. 4. In this experiment the pure substances $(50 \mu \mathrm{g}$. of each) were introduced at the top of the column as described above and the eluate was collected. Fig. 4 also shows the relationship between the position of the eluted substances and the solvent gradient.

The activities of the enzymes sulphatase and $\beta$-glucuronidase were determined by the method of Boyland et al. $(1955 b)$.

\section{RESULTS AND DISCUSSION}

Recovery values from urine were obtained by first estimating the amounts of test substances present in a normal sample $(25 \mathrm{ml}$.) of urine. The test substances were then added (10 or $100 \mu \mathrm{g}$. of each) to

Table 1. Recoveries of tryptophan metabolites added to urine

The amounts of metabolites indicated were added to $25 \mathrm{ml}$. of urine.

Anthranilic acid

3-Hydroxyanthranilic acid 3-Hydroxyanthranilic acid sulphuric ester

Kynurenine

3-Hydroxykynurenine

3-Hydroxykynurenine sulphuric ester

$\begin{array}{cr}\begin{array}{c}\text { Recovery (\%) after } \\ \text { addition of }\end{array} \\ \overbrace{100 \mu \mathrm{g} .} \begin{array}{r}10 \mu \mathrm{g} . \\ \text { of each } \\ \text { of each }\end{array} \\ 83,89 & 85,70 \\ 87,78 & 80,75 \\ 82,87 & 70,80 \\ 86,86 & 65,80 \\ 89,83 & 70,80 \\ 79,81 & 75,70\end{array}$


Table 2. Concentrations of tryptophan metabolites and enzyme activities of human urines

Mean concentrations of metabolites expressed as mg./l. are given with ranges in parentheses. Enzyme activities are expressed as units/ml.

No. of subjects

Mean volume of $24 \mathrm{hr}$. urine (ml.)

Anthranilic acid

3-Hydroxyanthranilic acid

3-Hydroxyanthranilic acid sulphuric ester

Kynurenine

3-Hydroxykynurenine

3-Hydroxykynurenine sulphuric

ester

Sulphatase

$\beta$-Glucuronidase

\begin{tabular}{|c|c|c|c|c|}
\hline \multicolumn{5}{|c|}{ Condition of subjects } \\
\hline \multirow[b]{2}{*}{ Normal } & \multirow[b]{2}{*}{$\begin{array}{l}\text { Cancer of } \\
\text { bladder }\end{array}$} & \multirow{2}{*}{$\begin{array}{c}\text { Cancer of } \\
\text { bladder } \\
\text { treated with } \\
4 \mathrm{~g} . \text { of sac- } \\
\text { charolactone/ } \\
\text { day }\end{array}$} & \multicolumn{2}{|c|}{$\begin{array}{l}\text { After administration of } \\
\text { DL-tryptophan (10 g.) }\end{array}$} \\
\hline & & & Normal & $\begin{array}{l}\text { Cancer of } \\
\text { bladder }\end{array}$ \\
\hline $\begin{array}{l}10 \\
1560 \\
12(6-23) \\
20(8-32) \\
9(5-12)\end{array}$ & $\begin{array}{l}10 \\
3420 \\
26(15-41) \\
44(18-82) \\
3(1-6)\end{array}$ & $\begin{array}{l}5 \\
3130 \\
8(5-9) \\
17(10-26) \\
7(5-10)\end{array}$ & $\begin{array}{l}5 \\
1320 \\
35(28-52) \\
43(21-76) \\
16(6-28)\end{array}$ & $\begin{array}{l}8 \\
2190 \\
70(27-97) \\
80(43-99) \\
20(10-37)\end{array}$ \\
\hline $\begin{array}{l}10(3-12) \\
2(0-5) \\
5(3-9)\end{array}$ & $\begin{array}{l}20(10-27) \\
5(2-9) \\
1(0-3)\end{array}$ & $\begin{array}{l}12(6-19) \\
5(3-6) \\
4(2-6)\end{array}$ & $\begin{array}{l}257(170-370) \\
56(21-91) \\
22(15-35)\end{array}$ & $\begin{array}{l}279(112-550) \\
92(35-171) \\
17(6-40)\end{array}$ \\
\hline $\begin{array}{l}(0.13-0.71) \\
(0.37-0.77)\end{array}$ & $\begin{array}{l}(0 \cdot 24-1 \cdot 8) \\
(0 \cdot 9-6 \cdot 6)\end{array}$ & $(0.0-\overline{0.3})$ & $(0.07-\overline{0.78})$ & $(0 \cdot 82-\overline{3 \cdot 2})$ \\
\hline
\end{tabular}

further $25 \mathrm{ml}$. samples of the urine and the process was repeated. The results obtained (Table 1) indicate recoveries of $78-89 \%$ at the $100 \mu \mathrm{g}$. level and $65-85 \%$ at the $10 \mu \mathrm{g}$. level.

Boyland et al. $(1955 a, b)$ suggested that 3hydroxyanthranilic acid and 3-hydroxykynurenine may, in their unconjugated forms, be responsible for the induction of cancer of the bladder in human subjects, as 3-hydroxyanthranilic acid has produced cancer of the bladder in mice (Boyland \& Watson, 1956). The present results show that the two $o$ aminophenols and their immediate precursors in the metabolic breakdown of tryptophan are present in greater concentrations in the urine of patients with cancer of the bladder than in normal subjects (Table 2). The differences in the output of these substances in $24 \mathrm{hr}$. are still greater because the urine volumes of the bladder-cancer patients, who are encouraged to drink large volumes of fluid, are about twice those of the normal subjects. Thus the mean daily output of 3-hydroxyanthranilic acid was $31 \mathrm{mg}$. for the normal subjects and $150 \mathrm{mg}$. for the bladder-cancer patients.

Administration of DL-tryptophan (10 g.) increased the excretion of all the substances estimated but the increases in the kynurenine derivatives were much greater than in the anthranilic acid derivatives (Table 2).

Patients suffering from cancer of the bladder have abnormally high $\beta$-glucuronidase and sulphatase activity (Boyland et al. 1955a,b). It is unlikely that the sulphatase plays any considerable part in the production of free carcinogens, because the sulphuric esters of $o$-aminophenols are either resistant to hydrolysis by sulphatase or are hydrolysed slowly (Boyland, Manson, Sims \& Williams, 1956). Treatment of cancer patients with gluco- saccharo-1:4-lactone causes a decrease in excretion of anthranilic acid, 3-hydroxyanthranilic acid and kynurenine, and an increase in excretion of the sulphuric esters. The apparent decrease in excretion of 3-hydroxyanthranilic acid is presumably due to inhibition of $\beta$-glucuronidase causing reduced hydrolysis of 3-hydroxyanthranilic acid glucosiduronate in the urine as the saccharolactone is a potent inhibitor of glucuronidase (Levvy, 1952). A number of such patients are now under treatment with glucosaccharo-1:4-lactone in the hope that reduction of excretion of free 3-hydroxyanthranilic acid will delay the recurrence of the disease.

\section{SUMMARY}

1. Anthranilic acid, 3-hydroxyanthranilic acid, 3-hydroxyanthranilic acid sulphuric ester, kynurenine, 3-hydroxykynurenine and 3-hydroxykynurenine sulphuric ester can be removed quantitatively from urine by use of a column of deactivated charcoal, and these six tryptophan metabolites can be separated and estimated by chromatography by a gradient-elution partition system.

2. Urines from patients with cancer of the bladder contain more anthranilic acid, 3-hydroxyanthranilic acid, kynurenine and 3-hydroxykynurenine and less 3-hydroxyanthranilic acid sulphuric ester and 3hydroxykynurenine sulphuric ester than urines from normal subjects.

3. Treatment of bladder-cancer patients with glucosaccharo-1:4-lactone appeared to reduce the excretion of anthranilic acid and 3-hydroxyanthranilic acid and to increase the excretion of 3-hydroxyanthranilic acid sulphuric ester and 3hydroxykynurenine sulphuric ester.

4. Administration of $10 \mathrm{~g}$. of DL-tryptophan increased the amounts of all these substances in the 
urine, particularly the kynurenine derivatives. Bladder-cancer patients dosed with tryptophan excreted larger amounts of anthranilic acid, 3 hydroxyanthranilic acid and 3-hydroxykynurenine.

We should like to thank Mr D. M. Wallace for his help in diagnosis and in arranging for the collection of specimens. This research was supported by grants to the Royal Cancer Hospital and Chester Beatty Research Institute from the British Empire Cancer Campaign, the Jane Coffin Childs Memorial Fund for Medical Research, the Anna Fuller Fund and the National Cancer Institute of the National Institutes of Health, U.S. Public Health Service.

\section{REFERENCES}

Bonser, G. M. (1943). J. Path. Bact. 55, 1.

Bonser, G. M., Clayson, D. B., Jull, J. W. \& Pyrah, L. M. (1952). Brit. J. Cancer, 6, 412.

Boyland, E., Manson, D., Sims, P. \& Williams, D. C. (1956). Biochem. J. $62,68$.

Boyland, E. \& Sims, P. (1954). J. chem. Soc. p. 980.
Boyland, E., Sims, P. \& Williams, D. C. (1956). Biochem. J. $62,546$.

Boyland, E., Wallace, D. M. \& Williams, D. C. (1955a). Brit. J. Urol. 18, 11.

Boyland, E., Wallace, D. M. \& Williams, D. C. (1955b). Brit. J. Cancer, 9, 62.

Boyland, E. \& Watson, G. (1956). Nature, Lond., 177, 837. Boyland, E. \& Williams, D. C. (1955a). Biochem. J. 60, v. Boyland, E. \& Williams, D. C. (1955b). Abstr. 3rd Int. Congr. Biochem., Brussels, p. 126.

Butenandt, A. \& Hellmann, G. (1950). Z. Naturf. B, 56, 445. Dalgliesh, C. E. (1952). Biochem. J. 52, 3.

Hueper, W. C., Wiley, F. H. \& Wolfe, H. D. (1938). J. industr. Hyg. 20, 46.

Hueper, W. C. \& Wolfe, H. D. (1937). Amer. J. Path. 13, 656.

Levvy, G. A. (1952). Biochem. J. 52, 464.

Morris, C.J. O. R. \& Williams, D. C. (1954). Ciba Foundation Colloquia Endocrin. vol. 8, p. 157. London: Churchill.

Randall, S. S. \& Martin, A. J. P. (1949). Biochem. J. 44, xi. Synge, R. L. M. \& Tiselius, A. (1949). Acta chem. scand. 3, 231.

\title{
Purification, some Properties and the Specific Biological Activity of Gytochromes $c_{4}$ and $c_{5}$ from Azotobacter vinelandii
}

\author{
By A. TISSIÈRES \\ Molteno Institute, University of Cambridge
}

(Received 2 May 1956)

The cytochrome system in bacterial cells varies from species to species, as shown by the positions of the absorption bands and by other properties of the individual components (Smith, 1954a). Thus cellfree preparations from certain bacteria lack cytochrome $c$ oxidase activity (Keilin \& Harpley, 1941), even when they are made from organisms in which the absorption bands of cytochrome lie at the same position as those found for heart muscle (Smith, $1954 b)$.

The earlier work was based upon direct spectroscopy of intact cells (Smith, 1954a) and only recently have some cytochrome components from bacteria been extracted and purified. Egami, Itahashi, Sato \& Mori (1953) obtained a soluble cytochrome from halotolerant bacteria, and in the same year Vernon (1953) and Elsden, Kamen \& Vernon (1953) isolated from the photosynthetic bacterium Rhodospirillum rubrum a pigment similar in several ways to cytochrome $c$. The pigment was, however, not oxidized by cytochrome $c$ oxidase preparations. Postgate (1954, 1955, 1956) described a soluble cytochrome from the sulphatereducing bacterium Desulphovibrio desulphuricans, and Gibson \& Larsen (1955) have isolated two cytochromes from Chlorobium thiosulphatophilum.
Kamen \& Vernon (1955) have studied the catalytic activity of purified cytochromes of the ' $c$ ' type from facultative photoheterotrophs as well as from denitrifiers and found that in most cases the bacterial pigments failed to react with cytochrome $c$ oxidase from heart muscle. They also reported (Kamen \& Vernon, 1954) that a ' $c$ '-type cytochrome and its oxidase from Azotobacter vinelandii reacted only with each other and could not be linked to a cytochrome c-cytochrome oxidase system from animal tissues.

The present paper deals with the extraction, purification and properties of two cytochromes from $A$. vinelandii, and their specific activity in the cytochrome and succinic oxidase systems in particulate preparations from the same bacterium. The soluble pigments are called here cytochromes $c_{4}$ and $c_{5}$ because in some essential properties they closely resemble cytochrome $c$. They were extracted from the cells by means of $n$-butanol, by a procedure similar to that of Morton (1950). Cytochrome $c_{5}$ has so far been isolated only in small amounts and has thus been less completely characterized than cytochrome $c_{4}$. A preliminary account of this work has already been published (Tissières \& Burris, 1956). 